\title{
Education in small states: Policies and priorities
}

\author{
By Michael Crossley, Mark Bray and Steve Packer. Commonwealth \\ Secretariat, London, 2011, 86 pp. ISBN 978-1-84929-036-4 (pbk); \\ ISBN 978-1-84859-088-5 (e-book)
}

\author{
Michael McVey
}

Published online: 9 June 2012

(C) Springer Science+Business Media B.V. 2012

Education in Small States: Policies and Priorities by Michael Crossley, Mark Bray and Steve Packer focuses primarily on small states in the Commonwealth, of which there are 33 out of 54 member countries in total. Size, in this report, refers generally to countries with populations below 1.5 million but may include larger ones considered in particular geographic groupings.

According to Crossley et al., two factors external to these small states appear to have had an impact over the last decade. Trade liberalisation has led to a brain drain for smaller nations, and global climate change has already wrought more intense weather events and an increased risk of inundation from rising sea levels. However, globalisation and improved technology have improved access to libraries and specialist advice that might be of assistance to these same countries. Tertiary education, the authors note, is now expanding in these areas.

The authors thoroughly explain the variance in needs of these countries with a special focus on island nations. One clear example of the difficulty of improving educational programmes in an island nation can be found in Vanuatu, with 13 larger and 70 smaller islands spread out over 1,300 kilometres. Isolated populations mean moving children from their home islands for education. The challenges are obvious and the pressure on families is real.

The book also clearly lays out issues of financial interconnectedness. For example, the falling prices of commodities such as oil may lead to reduced tourism in one country, and a burdensome debt in another country may mean a weakened ability to respond to short-term crises. Smaller states, the authors point out, are hit harder by such global economic shifts. The consequence of increasing poverty in a small state can be a real threat to educational progress.

This well-researched book, written with a minimum of jargon, helps to broadly explain the particular needs of a unique subset of states in the Commonwealth.

M. McVey (ه)

Eastern Michigan University, Ypsilanti, MI, USA

e-mail: mmcvey@emich.edu 